\title{
14. RADIOLARIANS FROM LEG 134, VANUATU REGION, SOUTHWESTERN TROPICAL PACIFIC ${ }^{1}$
}

\author{
Amy L. Weinheimer, ${ }^{2}$ Annika Sanfilippo, ${ }^{2}$ and W.R. Riedel ${ }^{2}$
}

\begin{abstract}
In the cores obtained during Leg 134 of the Ocean Drilling Program, radiolarians occur intermittently and usually in a poor state of preservation, apparently as a result of the region having been at or near the boundary between the equatorial current system and the south-central Pacific water mass during most of the Cenozoic. A few well-preserved assemblages provide a record of the Quaternary forms, and some displaced middle and lower Eocene clasts preserve a record of radiolarians near that subepochal boundary. There are less satisfactory records of middle Miocene and early Miocene to late Oligocene forms.
\end{abstract}

\section{INTRODUCTION}

The locations of Leg 134 drilling sites are indicated in Table 1. All of the cores from these sites were examined for radiolarians, but this microfossil group occurred so sparsely and intermittently (see Table 2) as to be much less useful for stratigraphic interpretations than were the calcareous groups.

Sufficient radiolarians occurred in the Quaternary sediments to provide a comprehensive documentation of this fossil group in this region. Rare, fragmentary radiolarians occur in lower middle Miocene samples, and in lower Miocene to upper Oligocene strata. Middle and lower Eocene clasts in the Pliocene sediments of Hole 827B contain sufficient radiolarians to distinguish two zones.

The nearest long drilled sequence with which the Leg 134 radiolarians can be compared is that recovered at Deep Sea Drilling Project Site 286 (at $16^{\circ} 31.92^{\prime} \mathrm{S}, 166^{\circ} 22.18^{\prime} \mathrm{E}$, in $4465 \mathrm{~m}$ of water; Holdsworth, 1975). At that site a well-preserved radiolarian assemblage is reported from the Quaternary, as are sparser, less well-preserved assemblages from the upper Eocene and Oligocene. There are some rich radiolarian assemblages in the middle Eocene (younger than the middle Eocene of Hole 827B).

\section{METHODS}

In general, one or two samples per core were examined for radiolarians. The samples were of about $15 \mathrm{~cm}^{3}$, and the first step was to prepare a smear slide. If no fragments of siliceous microfossils were found in the smear slide, the samples were returned to the ODP Curator. If the smear slide contained siliceous fragments, the sample was disaggregated by boiling with a solution of tetrasodium pyrophosphate and hydrogen peroxide, sieved through a mesh of $63 \mu \mathrm{m}$, and acidified if foraminifers were present. The resulting coarse fraction was mounted in a synthetic cement (Norland Optical) or Canada balsam. In most samples containing rare or few radiolarians, they were highly diluted by pyroclastic grains.

\section{ZONES}

Our usage of the Phormocyrtis striata and Theocotyle cryptocephala Zones is in accordance with the definitions by Sanfilippo et al. (1985) and our usage of the Quaternary Buccinosphaera invaginata Zone is in accordance with the definition of Nigrini (1971).

\footnotetext{
'Greene, H.G., Collot, J.-Y., Stokking, L.B., et al., 1994. Proc, ODP, Sci. Results, 134: College Station, TX (Ocean Drilling Program).

${ }^{2}$ Scripps Institution of Oceanography, University of California at San Diego, La Jolla, CA 92093-0220, U.S.A.
}

\section{RADIOLARIANS AT EACH SITE}

\section{Site 827}

One or two samples were examined from each of the cores from Hole $827 \mathrm{~A}$. The only radiolarians observed were single, well-preserved specimens in Samples 134-827A-1H-2, 129-135 cm, 134$827 \mathrm{~A}-4 \mathrm{H}-\mathrm{CC}$, and $134-827 \mathrm{~A}-10 \mathrm{H}-3,44-46 \mathrm{~cm}$. Rare sponge spicules occur in practically all of the samples. Single fragments of diatom frustules were found in Samples 134-827A-8H-4, 65-66 cm, and $134-827 \mathrm{~A}-12 \mathrm{H}-2,8-10 \mathrm{~cm}$. The scarcity of siliceous microfossils is evidently due principally to their dilution by the volcanogenic constituents of the sediments.

One or two samples were examined from each of Cores 134-827B$1 R$ through $-18 R$ and $-25 R$ through $-27 R$. The only radiolarians found were middle Eocene assemblages from clasts within the Pliocene matrix of Core 134-827B-11R. Since there are not even rare fragments of siliceous microfossils in the Neogene sediments of this hole, their absence is evidently due to dissolution, rather than to dilution by other sedimentary constituents.

The Eocene clasts contain abundant well-preserved radiolarians from the late early Eocene (Phormocyrtis striata Zone) and the early middle Eocene (Theocotyle cryptocephala Zone) (Table 3 ).

Observations concerning Core 134-827B-11R are: (1) Theocotyle, Theocotylissa, Thyrsocyrtis are under-represented, (2) there is a high proportion of spyrids and artostrobiids, and (3) many taxa display extreme morphological variation (see Pl. 1, Figs. 7-12). Some of the forms appear to have lived near the limits of their tolerance-short, highly silicified, small skeletons with irregular pore arrangements (e.g., Phormocyrtis striata, Thyrsocyrtis rhizodon, and Theocotyle nigriniae).

\section{Site 828}

One or two samples from each sedimentary core from Holes $828 \mathrm{~A}$ and $828 \mathrm{~B}$ were examined for radiolarians. All were barren except for individual, well-preserved specimens among the overwhelming sandsized mineral grains in the top four cores of Hole 828A. The absence of siliceous microfossils is probably due to their low rate of supply from the overlying water column, which is consistent with the location of this site beneath the South Pacific Central Gyre.

\section{Site 829}

Usually one sample per core was examined for radiolarians in Holes $829 \mathrm{~A}-829 \mathrm{C}$, for a total of about 100 samples. Some of the Quaternary samples contain very rare, moderately preserved radiolarians among the predominant sand-sized mineral grains: Samples 134-829A-3RCC, 134-829A-5R-CC, 134-829A-17R-CC, 134-829B-1H-CC, 134- 
Table 1. Longitudes and latitudes of Leg 134 drill holes.

\begin{tabular}{llll}
\hline Hole & Latitude (S) & Longitude (E) & $\begin{array}{c}\text { Water depth } \\
(\mathrm{m})\end{array}$ \\
\hline $827 \mathrm{~A}$ & $15^{\circ} 17.741^{\prime}$ & $166^{\circ} 21.116^{\prime}$ & 2803.4 \\
$827 \mathrm{~B}$ & $15^{\circ} 17.746^{\prime}$ & $166^{\circ} 21.112^{\prime}$ & 2803.4 \\
$828 \mathrm{~A}$ & $15^{\circ} 17.34^{\prime}$ & $166^{\circ} 17.04^{\prime}$ & 3086.7 \\
$828 \mathrm{~B}$ & $15^{\circ} 17.26^{\prime}$ & $166^{\circ} 16.96^{\prime}$ & 3082.0 \\
$829 \mathrm{~A}$ & $15^{\circ} 18.97^{\prime}$ & $166^{\circ} 20.7^{\prime}$ & 2905.2 \\
$829 \mathrm{~B}$ & $15^{\circ} 18.97^{\prime}$ & $166^{\circ} 20.7^{\prime}$ & 2909.0 \\
$829 \mathrm{C}$ & $15^{\circ} 18.96^{\prime}$ & $166^{\circ} 20.7^{\prime}$ & 2910.7 \\
$830 \mathrm{~A}$ & $15^{\circ} 57.00^{\prime}$ & $166^{\circ} 46.79^{\prime}$ & 1018.4 \\
$830 \mathrm{~B}$ & $15^{\circ} 56.997^{\prime}$ & $166^{\circ} 46.79^{\prime}$ & 1018.4 \\
$830 \mathrm{C}$ & $15^{\circ} 56.999^{\prime}$ & $166^{\circ} 46.7^{\prime}$ & 1008.9 \\
$831 \mathrm{~A}$ & $16^{\circ} 00.56^{\prime}$ & $166^{\circ} 40.34^{\prime}$ & 1066.4 \\
$831 \mathrm{~B}$ & $16^{\circ} 00.56^{\prime}$ & $166^{\circ} 40.35^{\prime}$ & 1066.4 \\
$832 \mathrm{~A}$ & $14^{\circ} 47.78^{\prime}$ & $167^{\circ} 34.35^{\prime}$ & 3089.3 \\
$832 \mathrm{~B}$ & $14^{\circ} 47.78^{\prime}$ & $167^{\circ} 34.35^{\prime}$ & 3089.3 \\
$833 \mathrm{~A}$ & $14^{\circ} 47.77^{\prime}$ & $167^{\circ} 52.78^{\prime}$ & 2629.9 \\
$833 \mathrm{~B}$ & $14^{\circ} 52.56^{\prime}$ & $167^{\circ} 52.78^{\prime}$ & 2629.0 \\
\hline
\end{tabular}

$829 \mathrm{C}-2 \mathrm{H}-\mathrm{CC}$, and $134-829 \mathrm{C}-7 \mathrm{H}-\mathrm{CC}$. In the tectonically disturbed Pliocene to Pleistocene and upper Oligocene to lower Miocene part of the section, sponge spicules are common in the core-catcher samples of Cores 134-829A-23R, 134-829A-26R through -29R, 134829A-33R through -37R, and 134-829A-39R, and in Sample 134$829 \mathrm{~A}-33 \mathrm{R}-1,47-50 \mathrm{~cm}$. In some of those samples the sponge spicules are accompanied by very rare fragments of Oligocene or early Miocene-age radiolarians, and in Sample 134-829A-38R-CC there are somewhat more radiolarians, which though badly fragmented, are sufficient to provide an approximate indication of age. In addition to rare fragments of carpocaniids, the following species are present: Calocycletta sp., Cyclampterium milowi, Didymocyrtis tubaria, Dorcadospyris sp., and Tristylospyris triceros, indicating an Oligocene or early Miocene age.

\section{Site 830}

Generally one sample from each of the cores from Holes 830A, $830 \mathrm{~B}$, and $830 \mathrm{C}$ was examined for radiolarians. The only specimens found were very rare fragments among dominant sand-sized mineral grains in Samples 134-830A-1H-2, 21-23 cm, and 134-830A-1HCC.

\section{Site 831}

Because of the reefal nature of the sediment column at this site, only one sample was examined for radiolarians: Sample 134-831A-1H-2, $73-75 \mathrm{~cm}$. It contains very rare radiolarians among the mineral grains.

\section{Site 832}

For the most part, one sample from each core of Holes 832A and $832 \mathrm{~B}$ was examined for radiolarians, supplemented by additional samples where initial results were encouraging. Sample 134-832A$1 \mathrm{H}-1,89-91 \mathrm{~cm}$, contains rather many well-preserved radiolarians, including phaeodarians. Few to very rare radiolarians occur in Quaternary samples below this, to about 540 mbsf: Samples 134-832A$1 \mathrm{H}-1,87-90 \mathrm{~cm} ; 832 \mathrm{~A}-1 \mathrm{H}-\mathrm{CC}$ (which contains many fragments of the diatom Ethmodiscus rex); 832A-2H-2, 108-110 cm; 832A-2H-2, $111-113 \mathrm{~cm}$; 832A-2H-CC; 832A-4H-5, 40-42 cm; 832A-4H-CC; $832 \mathrm{~A}-5 \mathrm{H}-2,20-22 \mathrm{~cm} ; 832 \mathrm{~A}-6 \mathrm{H}-2,51-53 \mathrm{~cm} ; 832 \mathrm{~A}-7 \mathrm{H}-2,71-73$ $\mathrm{cm} ; 832 \mathrm{~A}-7 \mathrm{H}-\mathrm{CC} ; 832 \mathrm{~A}-8 \mathrm{H}-2,30-32 \mathrm{~cm} ; 832 \mathrm{~A}-10 \mathrm{H}-\mathrm{CC} ; 832 \mathrm{~A}-$ $11 \mathrm{H}-2,40-42 \mathrm{~cm}$; 832B-1R-CC, 9-11 cm; 832B-3R-1, 33-35 cm; and $832 \mathrm{~B}-3 \mathrm{R}-\mathrm{CC}, 9-11 \mathrm{~cm}$.

The Quaternary fauna at Site 832 (Tables 4 and 5) includes species typically found in low-latitude areas (e.g., Siphonosphaera polysiphonia, Spongurus cf. elliptica, and Tetrapyle octacantha). Also present as frequently as these species are species common in cooler middle and high latitudes (e.g., Larcopyle butschlii, Spongotrochus glacialis, Spongurus sp., Cornutella profunda, Theocalyptra bicornis, and Theocalyptra davisiana $=$ Cycladophora davisiana $)$. In today's South Pacific Ocean, Subantarctic Mode and Antarctic Intermediate waters originating in the middle and high latitudes of the South Pacific can be traced to the area of Site 832 (Patterson and Whitworth, 1990). The cool-water species found at this site may indicate the occurrences of waters similar to these.

The samples yielded only two stratigraphically useful species: Buccinosphaera invaginata in Sample 134-832A-2H-2, 108-110 cm, and Collosphaera tuberosa in Samples 134-832A-1H-CC and 134$832 \mathrm{~A}-2 \mathrm{H}-2,108-110 \mathrm{~cm}$, which are very rare and rare, respectively (Table 4). Consequently, all that can be determined is that these samples probably belong in the Buccinosphaera invaginata Zone, the base of which is around 0.2 Ma (Johnson and Knoll, 1975; Johnson et al., 1989). The absence of additional marker species downcore is probably due to the fairly rare occurrence of radiolarians, making determination of any evolutionary events difficult. However, the sections with radiolarians (top 11 cores from Hole 832A and top three cores from Hole $832 \mathrm{~B}$ ) probably are not below the Collosphaera tuberosa Zone because no Axoprunum angelinum (= Stylatractus universus) was found. This cosmopolitan moderately robust species probably would be present if the core penetrated its last appearance datum (approximately $0.42 \mathrm{Ma}$, Morley and Shackleton, 1978).

The Tertiary part of the section is barren except for Cores 134832B-84R and $-85 R$, which contain a few altered radiolarians. Forms recognizable in Sample 134-832B-84R-2, 5-7 cm, are Cyrtocapsella tetrapera (rare), C. japonica (very rare), and Lithopera neotera (very rare), and fragments of Didymocyrtis violina, D. mammifera, D. laticonus, Calocycletta sp(p)., Theocyrtis sp(p)., Stichocorys sp(p)., Anthocyrtidium sp(p)., and rare indeterminate carpocaniids. The assemblage is tentatively interpreted as indicating the Dorcadospyris alata Zone (middle Miocene). Sample 134-832B-85R-4, 36-37 cm, contains some well-preserved diatoms and fragments of the radiolarian genera Stichocorys, Didymocyrtis, and Lamprocyclas.

\section{Site 833}

One or two samples from each core of Hole 833A were examined for radiolarians. Members of this fossil group were rare to common, poorly to well preserved, in most samples to a depth of $64 \mathrm{mbsf}$ : Samples 134-833A-1H-1, 11-13 cm (few, good preservation); 833A-1H-1, 116$118 \mathrm{~cm}$ (few, good); 833A-1H-CC (few, good); 833A-2H-1, 113-115 cm (common, good); 833A-2H-4, 99-101 cm (common, good); 833A-2HCC (common, good); 833A-3H-2, 68-70 cm (common, good); 833A$3 \mathrm{H}-6,110-120 \mathrm{~cm}$ (few, good); 833A-3H-CC (common, good); $833 \mathrm{~A}-4 \mathrm{H}-2,118-120 \mathrm{~cm}$ (few, moderate); 833A-6H-1, 126-129 cm (few, poor); and 833A-10H-1, 64-66 cm (rare, poor).

An attempt was made to concentrate the radiolarians from Hole $833 \mathrm{~A}$ by separating them from the volcanic sediment using the technique described in Nelson and Casey (1986). Basically, this method separates siliceous particles with low surface area (sand grains) from those with high surface area (radiolarians) by means of a surfactant that keeps the radiolarians afloat while the mineral grains sink. Apparently the difference in surface area between the volcanogenic constituents at Hole 833A and the radiolarians was not large enough for the two to separate. The core-catcher samples from the top three cores contained high enough concentrations of Quaternary radiolarians for tabulation (Tables 4 and 5), but no species indicative of particular Quaternary zones were encountered.

Generally one sample per sediment core was examined for radiolarians in Hole 833B. All were barren.

\section{SPECIES LIST}

The following list, in alphabetical order, gives bibliographic references to the taxa observed. The original description and presently used concept of the 
species, if different from the original, of most of the Quaternary species can be found in Nigrini and Moore (1979); likewise, for the Eocene species, most are in Sanfilippo et al. (1985). For those species not in either of these references, we cite the original species concept, and the present concept if it differs from the original. Plate and figure numbers in parentheses refer to illustrations of taxa in the assemblages studied.

Acrosphaera spinosa (Haeckel) forma C. Collosphaera spinosa Haeckel, 1862, p. 536, pl. 34, figs. 12, 13; Acrosphaera spinosa forma C (Haeckel), Boltovskoy and Riedel, 1980, p. 102, pl. 1, fig. 3.

Amphirhopalum ypsilon Haeckel. Nigrini and Moore, 1979, p. S75, pl. 10, figs. 1A-E.

Anthocyrtidium ophirense (Ehrenberg). Nigrini and Moore, 1979, p. N67, pl. 25, fig. 1.

Anthocyrtidium zanguebaricum (Ehrenberg). Nigrini and Moore, 1979, p. N69, pl. 25, fig. 2 ,

Artobotrys borealis (Cleve). Theocorys borealis Cleve, 1899, p. 33, pl. 3, fig. 5; Petrushevskaya, 1971, p. 238, pl. 82, figs. 7-12; Nishimura and Yamauchi, 1984, p. 66, pl. 55, figs. 10a, b (Pl. 1, Fig. 1).

Botryocyrtis scutum (Harting). Nigrini and Moore, 1979, p. N105, pl. 28, figs. $1 \mathrm{~A}, \mathrm{~B}$.

Botryostrobus aquilonaris (Bailey). Nigrini and Moore, 1979, p. N99, pl. 27, fig. 1.

Botryostrobus auritus/australis (Ehrenberg) group. Nigrini and Moore, 1979, N101, pl. 27, figs. 2A-D.

Buccinosphaera invaginata Haeckel, 1887, p. 99, pl. 5, fig. 11; Knoll and Johnson, 1975, p. 63, pl. 1, figs. 3-7 (Pl. 1, Fig. 4).

Buryella clinata Foreman. Sanfilippo et al., 1985, p. 668, Figs. 14.1a, b.

Buryella tetradica Foreman. Sanfilippo et al., 1985, p. 668, Figs. 14.3a, b.

Calocyclas hispida (Ehrenberg). Anthocyrtis hispida Ehrenberg, 1873, p. 216; 1875, pl. 8, fig. 2. Calocyclas hispida Foreman, 1973, p. 434, pl. 1, figs. $12-15$, pl. 9, fig. 18 .

Calocycloma ampulla (Ehrenberg). Eucyrtidium ampulla Ehrenberg, 1854b, pl. 36 , figs, $15 a-c ; 1873$, p. 225 ; 1875 , p. 70 , pl. 10, figs. 11, 12a-b. Calocycloma ampulla Foreman, 1973, p. 434, pl. 1, figs. 1-5, pl.9, fig. 20.

Calocycloma castum (Haeckel). Sanfilippo et al., 1985, p. 669, Fig. 14.4.

Ceratocyrtis articulata Ehrenberg, 1873, p. 218; 1875, pl. 20, fig. 4.

Collosphaera tuberosa Haeckel. Nigrini and Moore, 1979, p. S1, pl. 1, fig. 1 (PI. 1, Fig. 5).

Cornutella profunda Ehrenberg, 1854a, p. 31; Boltovskoy and Riedel, 1980, p. 123 , pl. 5 , fig. 6 .

Cyrtocapsella japonica (Nakaseko). Eusyringium japonicum Nakaseko, 1963, p. 193, text-figs. 20-21, pl. 4, figs. 1-3. Cyrtocapsella japonica Sanfilippo and Riedel, 1970, p. 452, pl. 1, figs. 13-15.

Cyrtocapsella tetrapera Haeckel. Sanfilippo et al., 1985, p. 670, Fig. 16.1a,b.

Cyrtolagena aglaolampa (Takahashi). Cyrtopera aglaolampa Takahashi, 1981, p. 255, pl. 40, figs. 7, 8; Nishimura and Yamauchi, 1984, p. 55, pl. 41, fig. 7 (Pl. 1, Fig. 3).

Dendrospyris fragoides Sanfilippo and Riedel, 1973, p. 526, pl. 15, figs. 8-13, pl. 31, figs. 13, 14.

Dictyocoryne profunda Ehrenberg. Nigrini and Moore, 1979, p. S87, pl. 12, fig. 1 .

Dictyocoryne truncatum (Ehrenberg). Nigrini and Moore, 1979, p. S89, pl. 12, figs. 2A, B.

Dictyophimus craticula Ehrenberg, 1873, p. 223; 1875, pl. 5, figs. 4, 5.

Dictyoprora amphora (Haeckel). Dictyocephalus amphora Haeckel, 1887, p. 1305, pl. 62, fig. 4. Theocampe amphora (Haeckel) group Foreman, 1973, p. 431 , pl. 8, figs. 7, 9-13, pl. 9, figs. 8, 9 (PI. 1, Fig. 13).

Dictyospyris discus Sanfilippo and Riedel, 1973, p. 527, pl. 16, figs. 4-8. pl. 32, figs. 4-7.

Dictyospyris gigas Ehrenberg, 1873, p. 224; 1875, pl. 19, fig. 6; Sanfilippo and Riedel, 1973, p. 527, pl. 16, figs. 9, 10, pl. 32, figs. 10, 11 .

Didymocyrtis mammifera (Haeckel). Sanfilippo et al., 1985, p. 658, Fig. 8.4.

Didymocyrtis laticonus (Riedel). Sanfilippo et al., 1985, p. 658, Figs. 8.5a, b.

Didymocyrtis tetrathalamus (Haeckel). Ommatartus tetrathalamus Nigrini and Moore, 1979, p. S49, pl. 6, figs. 1A-D.

Disolenia quadrata (Ehrenberg). Nigrini and Moore, 1979, p. S3, pl. 1, fig. 2.

Disolenia zanguebarica (Ehrenberg). Nigrini and Moore, 1979, p. S5, pl. 1, fig. 3 .

Dorcadospyris platyacantha (Ehrenberg). Petalospyris platyacantha Ehrenberg, 1873, p. 247; 1875, pl. 22, fig. 8 (Pl. 1, Fig. 7).

Euchitonia elegans (Ehrenberg). Nigrini and Moore, 1979, p. S83, pl. 11, figs. $1 \mathrm{~A}, \mathrm{~B}$.
Euchitonia furcata Ehrenberg. Nigrini and Moore, 1979, p. S85, pl. 11, figs. $2 \mathrm{~A}, \mathrm{~B}$.

Eucyrtidium acuminatum (Ehrenberg). Nigrini and Moore, 1979, p. N61, pl. 24 , figs. $3 \mathrm{~A}, \mathrm{~B}$.

Eucyrtidium anomalum (Haeckel). Lithocampe anomala Haeckel, 1860, p. 839; Petrushevskaya, 1971, p. 219, fig. 98; Boltovskoy and Riedel, 1987, pl. V, fig. 1.

Eucyrtidium calvertense Martin group. Eucyrtidium calvertense Martin, 1904, p. 450 , pl. 130, fig. 5; Hays, 1965, p. 181, pl. 3, fig. 4 (Pl. 1, Fig. 2).

Eucyrtidium hexagonatum Haeckel. Nigrini and Moore, 1979, p. N63, pl. 24, figs. 4A, B.

Eucyrtidium hexastichum (Haeckel). Lithostrobus hexastichus Haeckel, 1887, p. 1470, pl. 80, fig. 15. Eucyrtidium hexastichum (Haeckel), Petrushevskaya, 1971, p. 220; Boltovskoy and Riedel, 1980, p. 124, pl. 5, fig. 10.

Eucyrtidium punctatum (Ehrenberg) group. Cf. Lithocampe punctata Ehrenberg, 1844, p. 84; cf. Eucyrtidium punctatum (Ehrenberg), Ehrenberg, 1847 , p. 43 ; 1854b, pl. 22, fig. 24; Sanfilippo and Riedel, 1973, p. 221, pl. 5 , figs. $15,16$.

Giraffospyris angulata (Haeckel). Nigrini and Moore, 1979, p. N11, pl. 19, figs. $2 \mathrm{~A}-\mathrm{D}, 3 \mathrm{~A}, \mathrm{~B}$.

Giraffospyris cyrillium Sanfilippo and Riedel, 1973, p. 528, pl. 18, figs. 1-3, pl. 33 , fig. 3 .

Gondwanaria dogieli (Petrushevskaya). Sethoconus (?) dogieli Petrushevskaya, 1967, p. 94, pl. 53, figs. 1, 2. Gondwanaria dogieli (Petrushevskaya), Nishimura and Yamauchi, 1984, p. 51, pl. 33, fig. 15.

Heliodiscus asteriscus Haeckel. Nigrini and Moore, 1979, p. S73, pl. 9, figs. 1,2 .

Helotholus histricosa Jorgensen, 1905, p. 137, pl. 16, figs. 86-88; Benson, 1966, p. 459, pl. 31, figs. 4-8; Nishimura and Yamauchi, 1984, p. 45, pl. 24 , fig. 9.

Lamprocyclas maritalis Haeckel. Nigrini and Moore, 1979, p. N5, pl. 25, fig. 4. Lamprocyrtis nigriniae (Caulet). Nigrini and Moore, 1979, p. N81, pl. 25, fig. 7.

Lamprocyrtis (?) hannai (Campbell and Clark). Nigrini and Moore, 1979, p. N83, pl. 25, fig. 8.

Lamptonium fabaeforme fabaeforme (Krasheninnikov). Sanfilippo et al., 1985, p. 674 , fig. 18.2 .

Lamptonium fabaeforme constrictum Riedel and Sanfilippo, 1970. Sanfilippo et al., 1985, p. 674, fig. 18.4 .

Larcopyle butschlii Dreyer. Nigrini and Moore, 1979, p. S131, pl. 17, figs. $1 \mathrm{~A}, \mathrm{~B}$.

Larcospira quadrangula Haeckel. Nigrini and Moore, 1979, p. S133, pl. 17, fig. 2.

Liriospyris reticulata (Ehrenberg). Nigrini and Moore, 1979, p. N13, pl. 19, figs. $3 \mathrm{~A}, \mathrm{~B}$.

Lithelius minor Jorgensen. Nigrini and Moore, 1979, p. S135, pl. 17, figs. 3, $4 \mathrm{~A}, \mathrm{~B}$.

Lithochytris archaea Riedel and Sanfilippo, 1970, p. 528, pl. 9, fig. 7; Foreman, 1973, p. 436, pl. 2, figs. 4, 5 .

Lithochytris vespertilio Ehrenberg, 1873, p. 239; 1875, pl. 4, fig. 10; Riedel and Sanfilippo, 1970, p. 528, pl. 9, figs. 8, 9.

Lithocyclia ocellus Ehrenberg. Sanfilippo et al., 1985, p. 655, figs. 7.1a, b.

Lithopera bacca Ehrenberg, 1872, p. 297, pl. vii, fig. 1; Nigrini, 1967, p. 54-56, pl. 6, fig. 2.

Lophocyrtis biaurita (Ehrenberg). Eucyrtidium biauritum Ehrenberg, 1873 , p. 226; 1875, p. 70, pl. 10, figs. 7, 8. Lophocyrtis biaurita Foreman, 1973, p. 442 , pl. 8, figs. $23-26$.

Lychnocanoma bellum (Clark and Campbell). Lychnocanium bellum Clark and Campbell, 1942, p. 72, pl. 9, figs. 35, 39. Lychnocanoma bellum Foreman, 1973, p. 437, pl. 1, fig. 17, pl. 11, fig. 9.

Octopyle stenozona Haeckel. Nigrini and Moore, 1979, p. S123, pl. 16, figs. $2 \mathrm{~A}, \mathrm{~B}$.

Otosphaera auriculata Haeckel. Nigrini and Moore, 1979, p. S7, pl. 1, fig. 4.

Periphaena delta Sanfilippo and Riedel, 1973, p. 523, pl. 8, figs. 11, 12, pl. 27, figs. 6,7 .

Peripyramis circumtexta Haeckel. Nigrini and Moore, 1979, p. N29, pl. 21, figs. 4A, B.

Peromelissa phalacra (Haeckel). Psilomelissa phalacra Haeckel, 1887, p. 1208, 1209. Peromelissa phalacra (Haeckel), Petrushevskaya, 1971, p. 131, fig. 59, I, II.

Phormocyrtis striata striata Brandt. Sanfilippo et al., 1985, p. 679, figs. 20.1a, b (Pl. 1, Figs. 10a, b).

Phormostichoartus corbula (Harting). Nigrini and Moore, 1979, p. N103, pl. 27 , fig. 3 . 
Podocyrtis (Lampterium) acalles Sanfilippo and Riedel, 1992, p. 12, pl. 3, figs. 2-5 (PI. 1, Fig. 14).

Podocyrtis (Lampterium) aphorma Riedel and Sanfilippo, 1970, p. 532, pl. 11, fig. 2.

Podocyrtis (Lampterium) sinuosa Ehrenberg. Sanfilippo et al., 1985, p. 698, fig. 30.9.

Podocyrtis (Podocyrtis) papalis Ehrenberg, 1847, fig. 2; 1854b, pl. 36, fig. 23; 1873, p. 251; Sanfilippo and Riedel, 1973, p. 531, pl. 20, figs. 11-14, pl. 36 , figs. 2,3 .

Pterocanium praetextum praetextum (Ehrenberg). Nigrini and Moore, 1979 . p. N41, pl. 23, fig. 2.

Pterocanium trilobum (Haeckel). Nigrini and Moore, 1979, p. N45, pl. 23 , figs. $4 \mathrm{~A}-\mathrm{C}$.

Pterocorys macroceras (Popofsky). Lithopilium macroceras Popofsky, 1913, p. 377, figs. 91-93. Pterocorys macroceras (Popofsky), Petrushevskaya, 1971, p. 234, fig. 120; Caulet and Nigrini, 1988, p. 230, pl. 2, figs. 1-5.

Pterocorys zancleus (Muller). Nigrini and Moore, 1979, p. N89, pl. 25, figs. $11 \mathrm{~A}, \mathrm{~B}$.

? Pylospira octopyle Haeckel. Nigrini and Moore, 1979, p. S139, pl. 17, figs. $6 \mathrm{~A}-\mathrm{C}$.

Rhopalocanium ornatum Ehrenberg, 1847, fig. 3; 1854b, pl. 36, fig. 9; 1873 , p. 256; 1875, pl. 17, fig. 8; Foreman, 1973, p. 439, pl. 2, figs. 8-10, pl. 12, fig. 3 .

Sethochytris babylonis (Clark and Campbell) group. Dictyophimys babylonis Clark and Campbell, 1942, p. 67, pl. 9, figs. 32, 36; Riedel and Sanfilippo, 1970, p. 528, pl. 9, figs. 1-3.

Siphonosphaera polysiphonia Haeckel. Nigrini and Moore, 1979, p. S21, pl. 1 , figs. $6 \mathrm{~A}, \mathrm{~B}$.

Spongaster tetras Ehrenberg irregularis Nigrini. Nigrini and Moore, 1979, p. S95, pl. 13, fig. 2.

Spongaster tetras tetras Ehrenberg. Nigrini and Moore, 1979, p. S93, pl. 13, fig. 1.

Spongatractus pachystylus (Ehrenberg). Sanfilippo et al., 1985, p. 652, fig. 6.2 .

Spongocore puella Haeckel. Nigrini and Moore, 1979, p. S69, pl. 8, figs. $5 \mathrm{~A}-\mathrm{C}$.

Spongopyle osculosa Dreyer. Nigrini and Moore, 1979, p. S115, pl. 15, fig. 1.

Spongotrochus glacialis Popofsky group. Nigrini and Moore, 1979, p. S117, pl. 15, figs. 2A-D.

Spongotrochus (?) venustum (Bailey). Nigrini and Moore, 1979, p. S119, pl. 15 , figs. $3 \mathrm{~A}, \mathrm{~B}$.

Spongurus cf. elliptica (Ehrenberg). Nigrini and Moore, 1979, p. S63, pl. 8, fig. 2.

Stichocorys delmontensis (Campbell and Clark). Sanfilippo et al., 1985, p. 681 , figs. 23.1a, b.

Stylochlamydium asteriscus Haeckel. Nigrini and Moore, 1979, p. S113, pl. 14 , fig. 5 .

Stylodictya multispina Haeckel, 1860, p. 842; 1862, p. 496, pl. 29, fig. 5; Boltovskoy and Riedel, 1980, p. 118, pl. 4, fig. 4A, B.

Stylosphaera coronata sabaca Sanfilippo and Riedel, 1973, p. 521, pl. 1, fig. 18, pl. 25, figs. 7, 8 (PI. 1, Fig. 6).

Tessarastrum straussii Haeckel, 1887, p. 547, pl. 45, fig. 8; Boltovskoy and Riedel, 1987, pl. II, fig. 30.

Tetrapyle octacantha Muller. Nigrini and Moore, 1979, p. S125, pl. 16, figs. $3 \mathrm{~A}, \mathrm{~B}$.

Theocalyptra davisiana (Ehrenberg). Nigrini and Moore, 1979, p. N57, pl. 24 , figs. 2A, B.

Theocalyptra gegenbauri (Haeckel). Eucecryphalus gegenbauri Haeckel, 1860 , p. 836. Theocalyptra gegenbauri (Haeckel), Boltovskoy and Riedel, 1980, p. 126, pl. 5, fig. 18.

Theocorythium trachelium (Ehrenberg). Nigrini and Moore, 1979, p. N93, pl. 26 , fig. 2 .

Theocotyle cryptocephala (Ehrenberg). Sanfilippo et al., 1985, p. 685, figs. 25.2a, b (Pl. 1, Figs. 9a, b).

Theocotyle nigriniae Riedel and Sanfilippo. Sanfilippo et al., 1985, p. 685, figs. 25.1a, b (PI. 1, Figs. 8a, b).

Theocotylissa ficus (Ehrenberg). Sanfilippo et al., 1985, p. 686, figs. 25.7a, b (Pl. 1, Fig. 11).

Tholospyris fornicata Popofsky, 1913, p. 309, pl. 30, fig. 2; Renz, 1976, p. 177, pl. 8, fig. 15.

Thyrsocyrtis (Thyrsocyrtis) hirsuta (Krasheninnikov). Sanfilippo et al., 1985, p. 687 , fig. 26.2 .

Thyrsocyrtis (Thyrsocyrtis) rhizodon Ehrenberg. Sanfilippo et al., 1985, p. 687, figs. 26.3a, b (Pl. 1, Fig. 12).

\section{CONCLUSIONS}

The sparsity and poor state of preservation of the Neogene and Quaternary radiolarians in the Leg 134 cores is evidently a result of the region having been at or near the boundary between the equatorial current system and the south central Pacific water mass since the Oligocene. The abundant and diverse middle and early Eocene assemblages found in Hole 827B probably reflect conditions of higher biological productivity associated with the equatorial current system.

\section{ACKNOWLEDGMENTS}

This work was funded by JOI/USSAC. Samples were provided by the National Science Foundation. The manuscript was reviewed by Catherine Nigrini and David Lazarus.

\section{REFERENCES *}

Benson, R.N., 1966. Recent Radiolaria from the Gulf of California [Ph.D. dissert.]. Minnesota Univ., St. Paul.

Boltovskoy, D., and Riedel, W.R., 1980. Polycystine Radiolaria from the southwestern Atlantic ocean plankton. Rev. Esp. Micropaleontol., 12:99146.

1987. Polycystine Radiolaria of the California current region: seasonal and geographic patterns. Mar. Micropaleont., 12:65-104.

Caulet, J.P., and Nigrini, C., 1988. The genus Pterocorys (Radiolaria) from the tropical late Neogene of the Indian and Pacific Oceans. Micropaleontology, 34:217-235.

Clark, B.L., and Campbell, A.S., 1942. Eocene radiolarian faunas from the Monte Diablo area, California. Spec. Pap.-Geol. Soc. Am., 39:1-112.

Cleve, P.T., 1899. Plankton collected by the Swedish expedition to Spitzbergen in 1898. K. Sven. Vetenskapsakad. Handl., 32:1-51.

Ehrenberg, C.G., 1844. über 2 neue Lager von Gebirgsmassen aus Infusorien als Meeres-Absatz in Nord-Amerika und eine Vergleichung derselben mit den organischen Kreide-Gebilden in Europa und Afrika. K. Preuss. Akad. Wiss. Berlin, Berichte, 57-97.

, 1847. über die mikroskopischen kieselschaligen Polycystinen als machtige Gebirgsmasse von Barbados und über das Verhältniss der aus mehr als 300 neuen Arten bestehenden ganz eigenthumlichen Formengruppe jener Felsmasse zu den jetzt lebenden Thieren und zur Kreidebildung. Eine neue Anregung zur Erforschung des Erdlebens. K. Preuss. Akad. Wiss. Berlin, Berichte, 40-60.

, 1854a. Die systematische Charakteristik der neuen mikroskopischen Organismen des tiefen Atlantischen Oceans. K. Preuss. Akad. Wiss. Berlin, Berichte, 236-250.

, 1854b. Mikrogeologie: Das Erden und Felsen schaffende Wirken des unsichtbar kleinen selbstandigen Lebens auf der Erde: Leipzig (Leopold Voss).

, 1872. Mikrogeologische Studien über das kleinste Leben der Meeres-Tiefgrunde aller Zonen und dessen geologischen Einfluss. Abh. K. Akad. Wiss. Berlin, 131-139.

, 1873. Grössere Felsproben des Polycystinen-Mergels von Barbados mit weiteren Erlauterungen. K. Preuss. Akad. Wiss. Berlin, Monatsberichte, 213-263.

, 1875. Fortsetzung der mikrogeologischen Studien als GesammtUebersicht der mikroskopischen Palaontologie gleichartig analysirter Gebirgsarten der Erde, mit specieller Rücksicht auf den Polycystinen-Mergel von Barbados. Abh. K. Akad. Wiss. Berlin, 1-225.

Foreman, H.P., 1973. Radiolaria of Leg 10 with systematics and ranges for the families Amphipyndacidae, Artostrobiidae, and Theoperidae. In Worzel, J.L., Bryant, W., et al., Init. Repts. DSDP, 10: Washington (U.S. Govt. Printing Office), 407-474.

Haeckel, E., 1860. Fernere Abbildungen und Diagnosen neuer Gattungen und Arten von lebenden Radiolarien des Mittelmeeres. K. Preuss. Akad. Wiss. Berlin, Monatsberichte, 835-845.

, 1862. Die Radiolarien (Rhizopoda Radiaria). Berlin (Reimer).

\footnotetext{
* Abbreviations for names of organizations and publications in ODP reference lists follow the style given in Chemical Abstracts Service Source Index (published by American
} Chemical Society). 
1887. Report on the Radiolaria collected by H.M.S. Challenger during the years 1873-1876. Rep. Sci. Results of the Voyage of the H.M.S. Challenger, Zoology, 18:1-1803.

Hays, J.D., 1965. Radiolaria and late Tertiary and Quaternary history of Antarctic Seas. In Llano, G.A. (Ed.), Biology of Antarctic Seas II. Am. Geophys. Union, Antarct. Res. Ser., 5:125-184.

Holdsworth, B.K., 1975. Cenozoic Radiolaria biostratigraphy, Leg 30: tropical and equatorial Pacific. In Andrews, J.E., Packham, G., et al., Init. Repts. DSDP, 30: Washington (U.S. Govt. Printing Office), 499-537.

Johnson, D.A., and Knoll, A.H., 1975. Absolute ages of Quaternary radiolarian datum levels in the equatorial Pacific. Quat. Res., 51:99-110.

Johnson, D.A., Schneider, D.A., Nigrini, C.A., Caulet, J.P., and Kent, D.V., 1989. Pliocene-Pleistocene radiolarian events and magnetostratigraphic calibrations for the tropical Indian Ocean. Mar. Micropaleontol., 14:33-66.

Jorgensen, E., 1905. The protist plankton and the diatoms in bottom samples. Bergens Mus. Skr., 49-151.

Knoll, A.H., and Johnson, D.A., 1975. Late Pleistocene evolution of the collosphaerid radiolarian Buccinosphaera invaginata Haeckel. Micropaleontology, 21:60-68.

Martin, G.C., 1904. Radiolaria, Miocene: Baltimore (Maryland Geol. Surv., Johns Hopkins Press), 447-459.

Morley, J.J., and Shackleton, N.L., 1978. Extension of the radiolarian Stylatractus universus as a biostratigraphic datum to the Atlantic Ocean. Geology, 6:309-311.

Nakaseko, K., 1963. Neogene Cyrtoidea (Radiolaria) from the Isozaki Formation in Ibaraki Prefecture, Japan. Sci. Rep., Coll. Gen. Educ. Osaka Univ., 12:165-198.

Nelson, C.O., and Casey, R.E., 1986. Siliceous microfossil extraction from altered Monterey rocks. In Casey, R.E., and Barron, J.A. (Eds.), Siliceous Microfossils and Microplankton of the Monterey Formation and Modern Analogs. Spec. Publ.-Pacific Sect., Soc. Econ. Paleontol. Mineral., 45:91-96.

Nigrini, C., and Moore, T.C., Jr., 1979. A Guide to Modern Radiolaria. Spec. Publ.-Cushman Found. Foraminiferal Res., 16:i-xii, S1-S142, N1-N106.

Nigrini, C.A., 1967. Radiolaria in pelagic sediments from the Indian and Atlantic Oceans. Bull. Scripps Inst. Oceanogr., 11:1-125,

Nigrini, C.A., 1971. Radiolarian zones in the Quaternary of the equatorial Pacific Ocean. In Funnell, B.M., and Riedel, W.R. (Eds.), The Micropalaeontology of Oceans: Cambridge (Cambridge Univ. Press), 443-461.

Nishimura, A., and Yamauchi, M., 1984. Radiolarians from the Nankai Trough in the Northwest Pacific. News Osaka Micropaleontol., Spec. Vol., 6:1-148.
Patterson, S.L., and Whitworth, T., 1990. Physical oceanography. In Glasby, G.P. (Ed.), Antarctic Sector of the Pacific: Amsterdam (Elsevier Oceanogr. Ser.), 55-94.

Petrushevskaya, M.G., 1967. Radiolyarii otryadov Spumellaria i Nassellaria antarkticheskoi oblasti (Antarctic Spumelline and Nasselline radiolarians). Issled. Fauny Morei, 4:1-186.

1971. Radiolyarii Nassellaria v planktone mirovogo okeana (Radiolarians of the Ocean). Issled. Fauny Morei, 9:1-294.

Popofsky, A., 1913. Die Nassellarien des Warmwassergebietes (Nassellaria from warm water areas). In Drygalski, E. (Ed.), Dtsch. Sudpolar-Exped., 1901-1903, 14 (Zool. Vol. 6):217-416.

Renz, G.W., 1976. The distribution and ecology of Radiolaria in the Central Pacific plankton and surface sediments. Bull. Scripps Inst. Oceanogr., 22:1-267.

Riedel, W.R., and Foreman, H.P., 1961. Type specimens of North American Paleozoic Radiolaria. J. Paleontol., 35:628-632.

Riedel, W.R., and Sanfilippo, A., 1970. Radiolaria, Leg 4, Deep Sea Drilling Project. In Bader, R.G., Gerard, R.D., et al., Init. Repts. DSDP, 4: Washington (U.S. Govt. Printing Office), 503-575.

Sanfilippo, A., and Riedel, W.R., 1970. Post-Eocene "closed" theoperid radiolarians. Micropaleontology, 16:446-462.

1973. Cenozoic Radiolaria (exclusive of Theoperids, Artostrobiids and Amphipyndacids) from the Gulf of Mexico, Deep Sea Drilling Project Leg 10. In Worzel, J.L., Bryant, W., et al., Init. Repts. DSDP, 10: Washington (U.S. Govt. Printing Office), 475-611.

1992. The origin and evolution of Pterocorythidae (Radiolaria): a Cenozoic Phylogenetic study. Micropaleontology, 38:1-36.

Sanfilippo, A., Westberg-Smith, M.J., and Riedel, W.R., 1985. Cenozoic Radiolaria. In Bolli, H.M., Saunders, J.B., and Perch-Nielsen, K. (Eds.) Plankton Stratigraphy: Cambridge (Cambridge Univ. Press), 631-712.

Takahashi, K., 1981. Vertical flux, ecology and dissolution of Radiolaria in tropical oceans: implications for the silica cycle [Ph.D. dissert.]. Woods Hole Oceanographic Inst., Woods Hole.

Date of initial receipt: 27 March 1992

Date of acceptance: 12 June 1992

Ms 134SR-013 
Table 2. Overview of radiolarian material recovered.

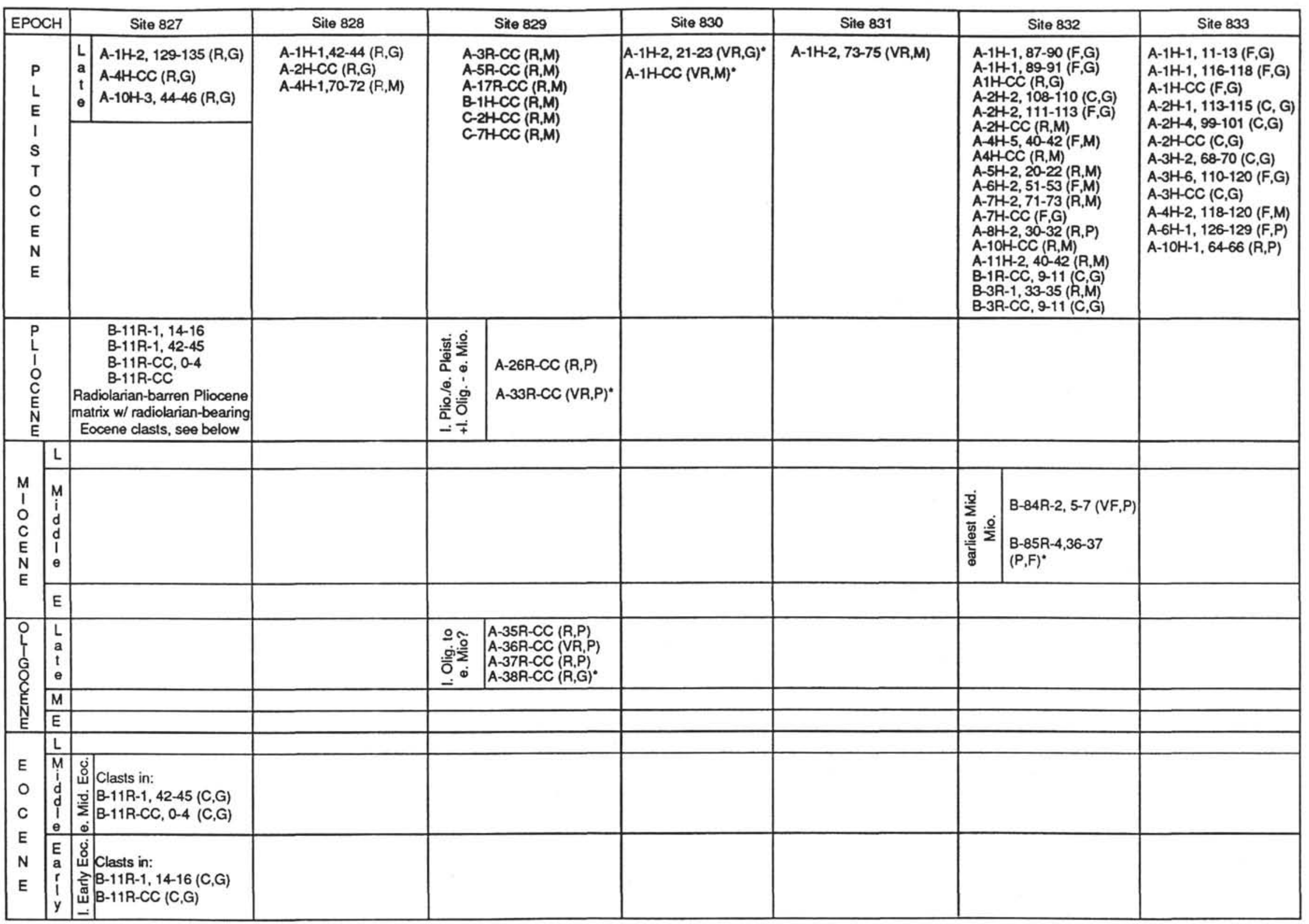

Notes: In parentheses are indications of abundance and preservation: $\mathrm{VR}=$ very rare, $\mathrm{R}=$ rare, $\mathrm{F}=$ few, $\mathrm{C}=$ common, $\mathrm{A}=$ abundant, $\mathrm{P}=$ poor, $\mathrm{M}=$ moderate, $\mathrm{G}=$ good. An asterisk indicates that the radiolarians found were fragments only. 
Table 3. Occurrences of species in upper lower Eocene and lower middle Eocene samples from Hole 827B.

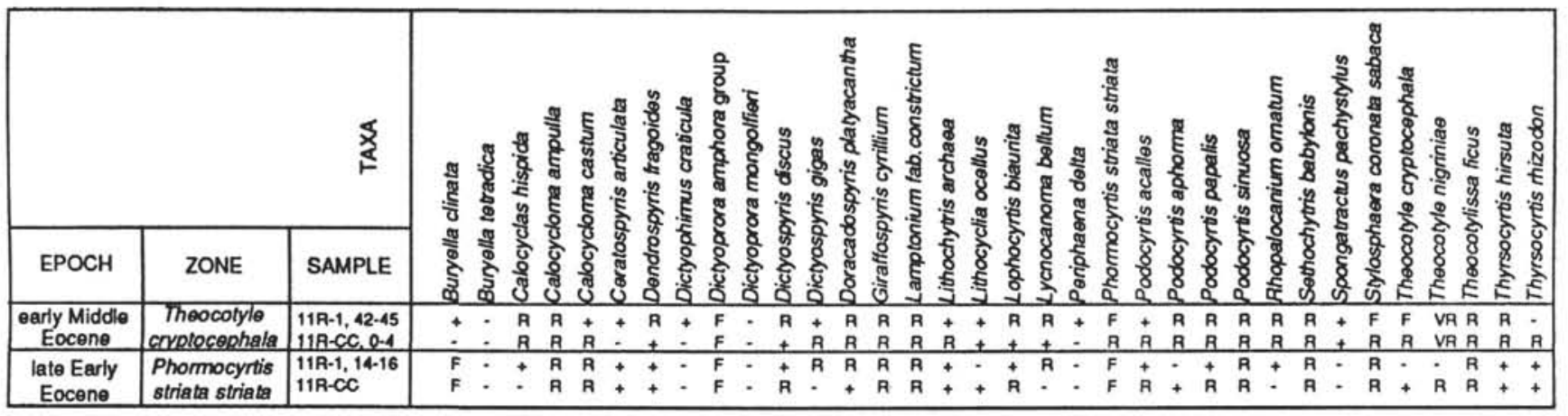

Notes: Abundances are common $(\mathrm{C})=>10 \%$, few $(\mathrm{F})=1 \%-10 \%$, rare $(\mathrm{R})=0.1 \%-1 \%$, very rare $(\mathrm{VR})=0.01 \%-0.1 \%$, "+" less than $0.01 \%$ of the total assemblage. A dash indicates that a taxon was looked for but not found in the assemblage. Abundances and preservations of assemblages are shown in Table 2.

Table 4. Occurrences of spumellarians in Quaternary cores of Holes 832A, 832B, and 833A.

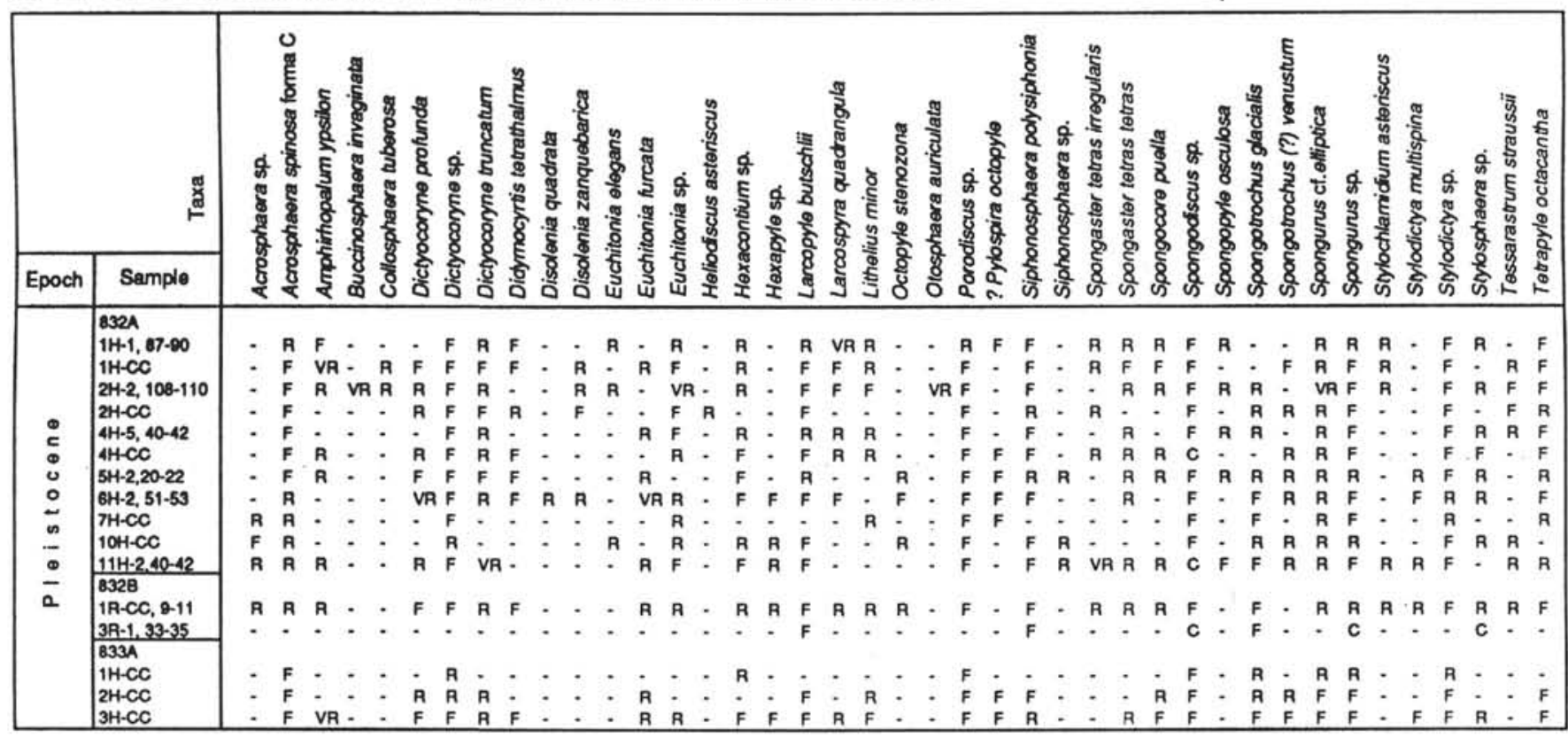

Notes: A dash indicates that a taxon was looked for but not found in the assemblage. Abundances and preservations of assemblages are shown in Table 2. For explanation of abundance codes, see Table 3. 
Table 5. Occurrences of nassellarians in Quaternary cores of Holes 832A, 832B, and 833A.

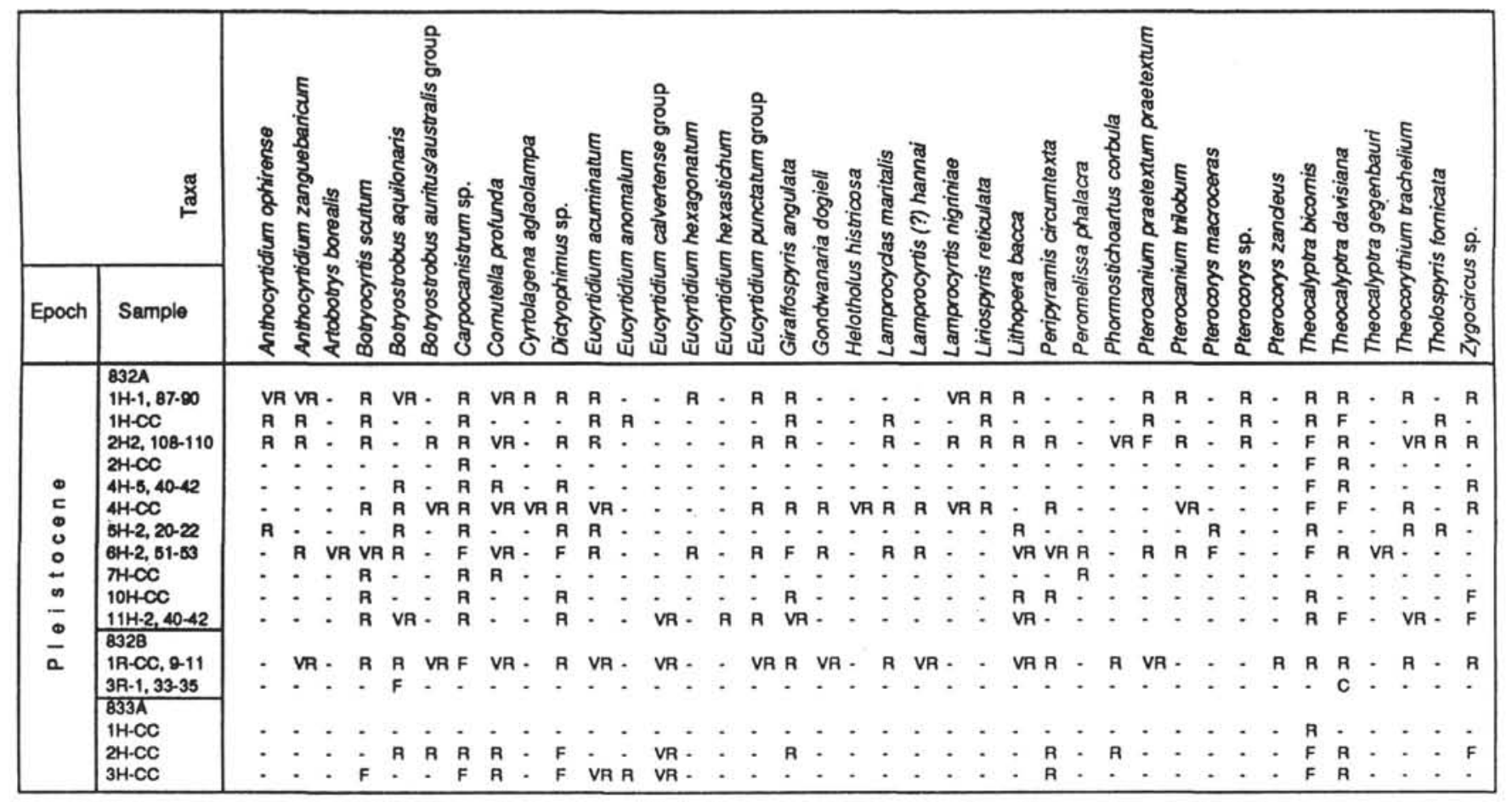

Notes: A dash indicates that a taxon was looked for but not found in the assemblage. Abundances and preservations of assemblages are shown in Table 2. For explanation of abundance codes, see Table 3. 


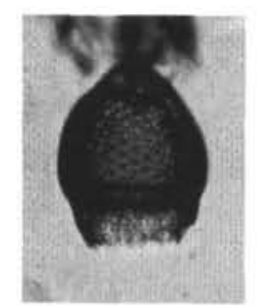

1

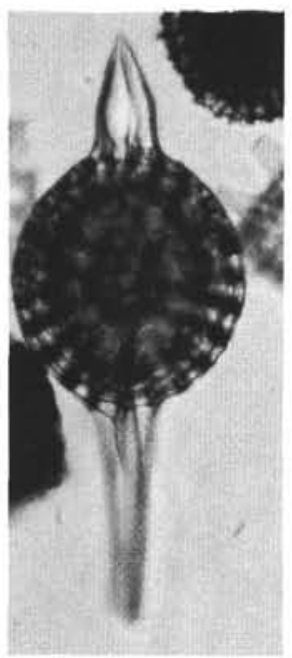

6

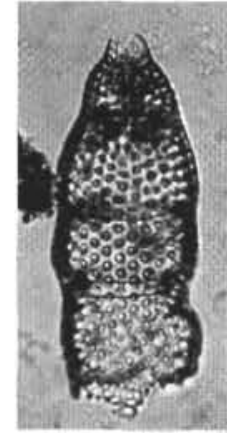

2

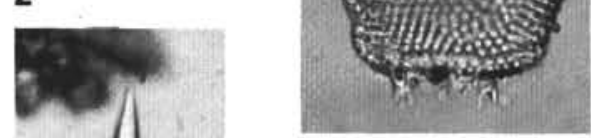

3

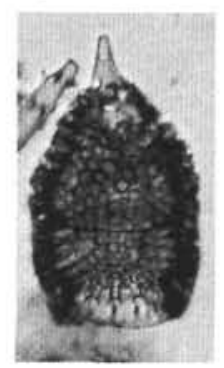

$8 \mathrm{a}$

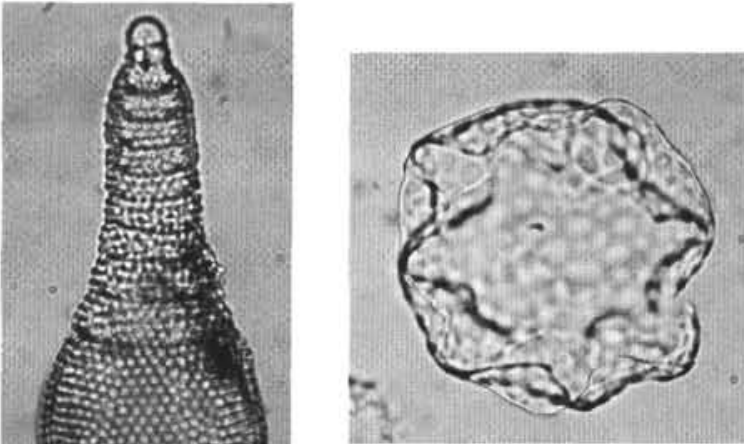

4

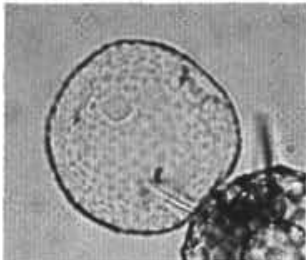

5

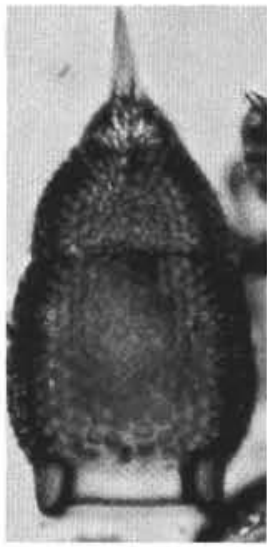

$9 b$
7

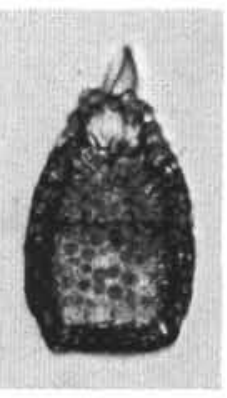

$8 b$

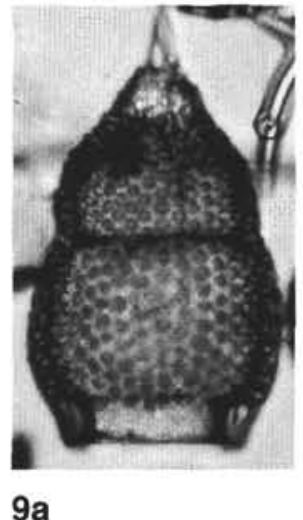

9a

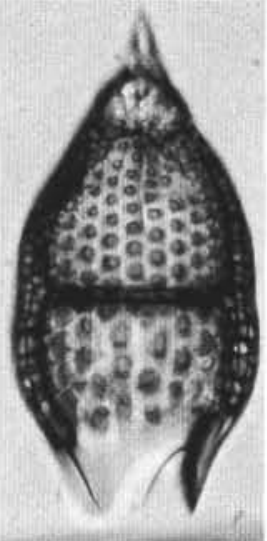

14

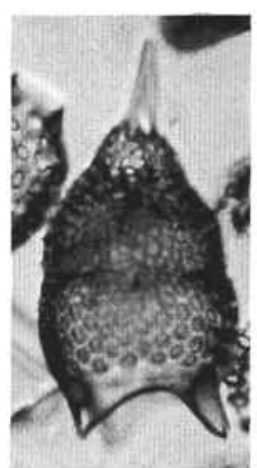

12

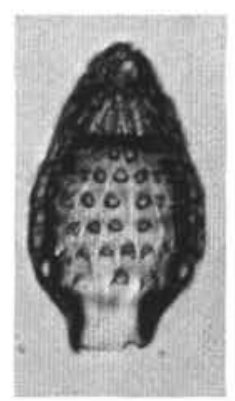

13

$10 \mathrm{~b}$

11

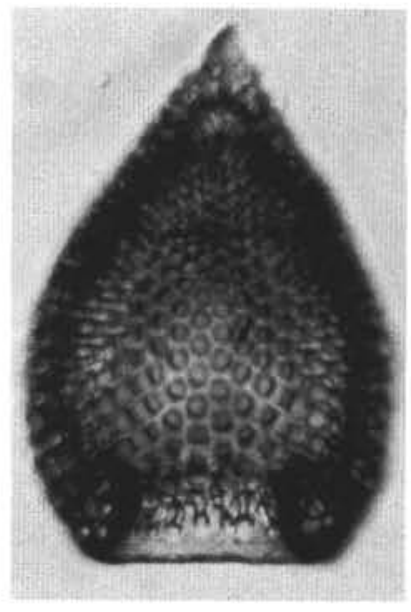

11

Plate 1. Numbers preceded by "sl." indicate slides in our collection at Scripps Institution of Oceanography; an annotation in the form U35/1 indicates an England Finder position (Riedel and Foreman, 1961) of the illustrated specimen on the slide. All specimens magnified 235×. 1. Artobotrys borealis, Sample 134-832A-6H-2, 51-53 cm, sl. 1, P17/3. 2. Eucyrtidium calvertense group, Sample 134-832A-11H-2, 40-42 cm, sl. 1, S13/0. 3. Cyrtolagena aglaolampa, Sample 134-832A-4H-CC, s1. 1, N11/3. 4. Collosphaera tuberosa, Sample 134-832A-2H-22, 108-110 cm, sl. 1, S34/3. 5. Buccinosphaera invaginata, Sample 134-832A-2H-2, 108-110 cm, sl. 1, O19/0. 6. Stylosphaera coronata sabaca, Sample 134-827B-11R-1, 42-45 cm, sl. 2, X40/0. 7. Dorcadospyris platyacantha, Sample 134-827B-11R-1, 42-45 cm, sl. 1, P37/3 (note robust horn). 8a, b. Theocotyle nigriniae, Sample 134-827B-11R-CC: (a) small thick-walled specimen with peristome, T31/2; (b) small thick-walled, distally closed specimen, V14/2. 9a, b. Theocotyle cryptocephala, Sample 134-827B11R-1, 42-45 cm, sl. 1: (a) Q19/0; (b) M13/2. 10a, b. Phormocyrtis striata striata: (a) small form, Sample 134-827B-11R-1, 42-45 cm, sl. 1, S12/2; (b) Sample 134-827B-11R-1, 42-45 cm, sl. 1, L27/3. 11. Theocotylissa ficus, Sample 134-827B-11R-1, $42-45 \mathrm{~cm}$, sl. 1, L51/0, early morphotype. 12. Thyrsocyrtis rhizodon, Sample 134-827B-11R-1,4-16 cm, sl. 2, Q25/4, small morphotype. 13. Dictyoprora amphora group, Sample 134-827B-11R-1, 14-16 cm, sl. 2, Q27/3. 14. Podocyrtis acalles, Sample 134-827B-11R-1, $42-45 \mathrm{~cm}, \mathrm{sl} .1, \mathrm{~K} 47 / 0$. 